\title{
STUDENTS' DECISION IN SELECTING PRIVATE UNIVERSITIES IN PALEMBANG CITY
}

\author{
Mico Sastra $^{1 *}$, Syamsurijal $^{2}$, Robiani Bernadette $^{3}$, Shihab Muchsin Saggaff $^{4}$ \\ ${ }^{1}$ STIE Lembah Dempo Pagar Alam, Indonesia \\ 2,3 University of Sriwijaya, Palembang, Indonesia \\ ${ }^{4}$ University of Bakrie, Jakarta, Indonesia \\ *E-mail: sastra.mico@yahoo.com
}

\begin{abstract}
This research aimed at examining and analyzing the influence of promotion, service quality, and permanent university characteristic on students' decision in selecting private universities in Palembang city, as well as examining and analyzing whether permanent characteristic mediated the influence of promotion on students' decision in selecting private universities in Palembang city. The research conducted was explanatory research. The data analysis technique used in this research was Structural Equation Modeling (SEM) using tools AMOS. The research results show that the university selection decision is proven to significantly influenced by promotion and service quality. Permanent university characteristic variable became the moderating variable which can increase the influence of promotion on university selection decision. Promotion variable significantly contributed to university selection decision, while service quality did not influence the University Selection Decision.
\end{abstract}

\section{KEY WORDS}

Promotion, service quality, university permanent characteristics, selection decision.

The competition in the world of education is tight along with increasing and developing university growth. The education stakeholders are getting more challenges in obtaining new student candidates. On the other hand, the consumer candidate tends to become more sensitive to the value offered by each university. Moreover, in this condition, marketing is the battle of consumers' perceptions and no more about products (Kartajaya, 2007). With the variations of universities offered to the society, it makes the student candidates need to be more selective in choosing the most capable university to fulfill their needs.

Considering such condition, then consumer and consumer candidates' demand on the attributes and educational service performance that they obtain stimulate the intensity increase in the competition between educational service provider and universities. In this case, the university needs to implement the appropriate marketing strategies so that they can offer educational services according to the needs and expectations of the student candidates. One of the crucial strategies which influences the consumers in selecting a product is the promotional activities. Promotion according to Kotler and Armstrong (2012), "Promotion means activities that communicate the merits of the product and persuade target customers to buy it" meaning that promotion is an act of communicating the benefits of a product and persuading the consumer target to buy certain products.

Promotion can influence the consumers' behavior in making the purchasing decision or in this case the decision to choose the university. Promotion is an activity assigned to influence the consumers so that they will know the product and service offered by the company to them and they will be pleased to always buy the product and service (Gitosudarmo 2010).

The promotion in the university introduction to the new prospective students is significantly essential because it enables the prospective students to know the university profile so that it influences their decision to select the specific university. Besides promotion, service quality also an important factor and root in giving the satisfaction to the customers related to the words of mouth behavior such as complaints, recommendation, and exchange or movement (Yavas, Benkenstein \& Stuhldreier, 2004). Oliver (2007) explains that the customer's satisfaction is a part of marketing and plays vital role in the market. According to 
Bowen \& Booms (1983), service quality is the measurement of how good the level of given service can be received according to the customer expectation.

In order to increase the qualified service quality strategy, the company can use a service quality (SERVQUAL) measurement model to measure whether a customer is satisfied or not and influence the next respond or service consumption pattern (Tjiptono, 2010). With a good quality of service, the students who are studying or have been studying in the university can share their satisfaction with the new student candidates so that it will influence them in choosing certain universities. Another important factor influencing the university selection decision is the university permanent characteristics. Chapman (1981) reveals that the permanent university characteristic consisting of location, fees, and the expected program availability influence the university selection.

The current demand on the university is not only limited to the capability in generating the qualified graduates measured academically, but also through the proof of good accountability. This proof can be obtained through certification, for example, accreditation and ISO. Generally, the demand loaded and expected by society to the university includes quality assurance, quality control, and quality improvement (Badan Akreditasi Nasional Universitas, 1998).

With the increase of competition between universities, the universities face the challenges of recruiting an adequate number of students each year (Johnston, 2010). The tight competition between universities in obtaining the new student candidates makes the educational institution to offer the best service so that the benefits are received by a more significant number of students and it will increase the students' competitiveness.

The previous studies conducted were to identify the factors influencing the university decision selection, among them are Joseph and Joseph (1998); Joseph and Joseph (2000); Sidin, Hussin and Tan (2003); Lin (1997) and Gray, Fam and Llanes (2003). The previously conducted studies developed various variables including promotion variable concept such as in the research by Karp (2012); Cabrera and Nasa (2000). Research on service quality and permanent university characteristic has been frequently conducted among them are studies by Briggs (2007); Ceja (2006); Ancheh, Krishnan, and Nurtjahja (2007); as well as the newest research by Rudhumbu (2017). Based on the explanation in the background and review of previous research, there were not many studies conducted which study specifically on the influence of promotion, service quality, and permanent university characteristic on student's' decision in selecting private universities in Palembang city. Therefore, this research has innovation in permanent university characteristic variable in the selection decision and free from duplication and replication.

\section{LITERATURE REVIEW}

Consumer Behavior and Decision-Making. The most common model from this perspective is the Utility Theory which proposes that the consumer makes a choice based on the results expected from their decision. The consumer is perceived as the rational decision maker who only care about their own interest (Schiffman \& Kanuk, 2007; Zinkhan, 1992) where the utility theory regards consumer as 'a rational economic being' (Zinkhan 1992), a contemporary research on consumer behavior considers various factors which influence consumers and acknowledging different consumption activities outside the purchase. These activities commonly include the needs of acknowledgment, information search, alternative evaluation, establishing buying interest, purchasing behavior, consumption, and finally wastage. Schiffman \& Kanuk (2007:3) take a similar approach in defining the consumer behavior which is the displayed behavior by the consumer in searching, buying, using, evaluating, and throwing away the product or service that they expect will fulfill their needs".

Theory of Consumer Decision. The consumer decision model is also known as Blackwell, Miniard \& Engel (2001). Model which was developed first in 1968 by Engel, Kollat, and Blackwell, this model can be seen in Figure 1. The model was formed by six points of the decision-making process: the appearance of needs, followed by information search, both internally and externally, alternative evaluation, purchasing, consumption, and evaluation 
post purchasing. This purchasing decision is influenced by three main factors, first stimuli obtained from the marketing effort. Second, external environment variable consisting of consumer resource, motivation, knowledge, behavior, personality, value, and lifestyle. Consumer Decision Model became important in this research because it was utilized to explain the purchasing decision-making, both complex and simple characteristics. The complex consumption problems need external information search which was more extensive. Meanwhile, a simple purchasing issue can only depend on the internal search of a memory of past experiences.

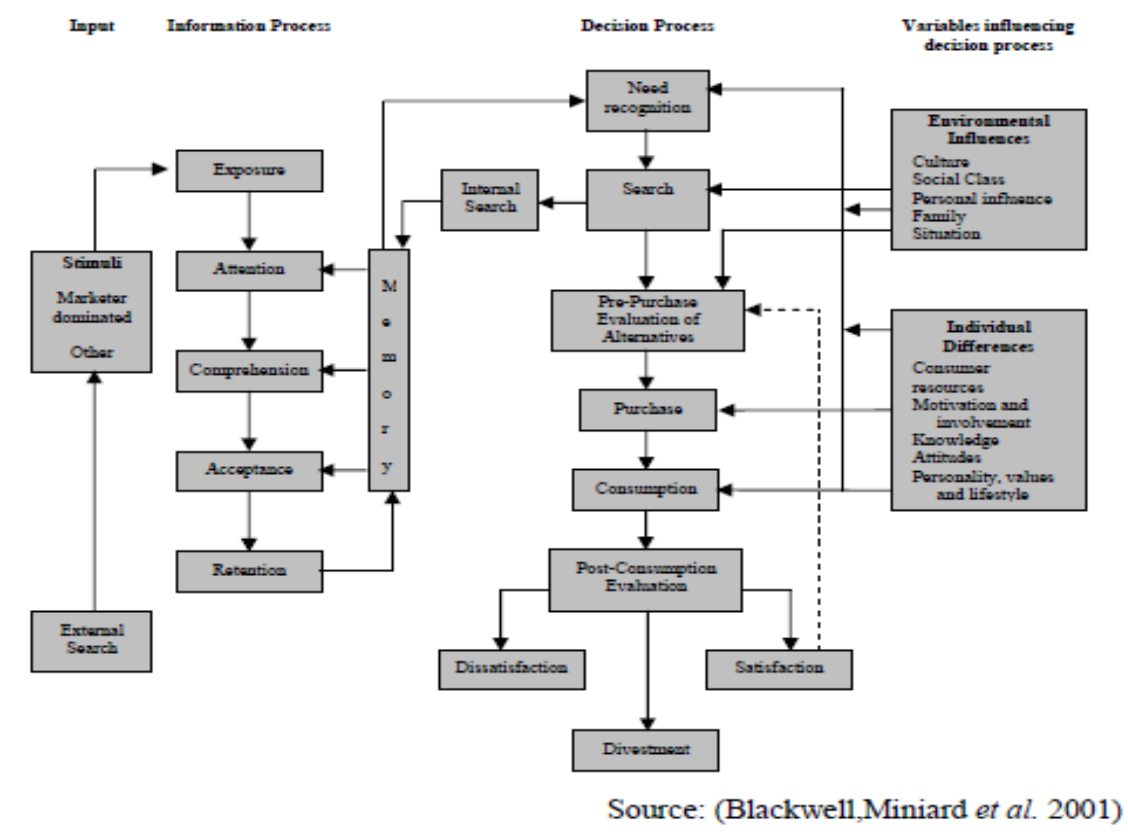

Figure 1 - Consumer Decision Model

University Selection Decision. The process of university selection decision by the student candidates or often called "consumer buying behavior" Kotler and Fox (1995) explain how an individual, group, or organization chooses, decide to buy, wear, and repurchase on the product or service to satisfy their needs and wants, and this concept also explains the factors influencing that specific behavior (Kotler and Armstrong, 2008). The process in decision-making is a complex activity and, in this research, the process adopts the decisionmaking model (student choice model) by Kotler (1997), which consists of identification of needs and motivation, information search, alternative evaluation, decision making, and postselection evaluation.

Service Promotion. According to Burnett (2000), promotion is a marketing activity to communicate the company and the products to the consumers, so that it creates demands. To be able to communicate their product effectively, the company needs first to determine the target market and then combines the promotion tools, namely advertisement, sales promotion, public relation, direct marketing, and salesperson in such a way so that the consumers can know the company's products and interested in buying the product. The promotion of service includes several main aspects known as promotion mix or communication mix (Payne, 2000), namely (a) advertisement, (b) individual sales, (c) sales promotion, (d) public relation.

Service Quality. Service Quality by Lewis \& Booms (1983) is defined as the measurement of how good the given service rate is, to match with the consumer's expectation. Besides, Parasuraman et al. (2004) state that two main factors influencing the service quality are: customer perception of the real perceived service; the actual expected service. 
Accordingly, the service quality can be measured from the comparison between the expected service and perceived service. If related to the context of the service quality in the university as the education service provider, then the aspect being compared is the student expectation and the perceived university performance. Therefore, in the end, we can acquire their customer satisfaction which becomes one of the standards to see the service quality. To understand further regarding any aspect $r$ direction of the service quality at this university, it is explained in the description below. There are various experts' opinions regarding what has become a dimension or elements of the service quality. Garvin (1987) states that service quality has eight dimensions, namely: performance, features, reliability, conformance to specifications, durability, serviceability, aesthetics, perceived quality.

Permanent university characteristic. Chapman (1981:495) states that location, fess, and the availability of the expected programs included in this model are the relatively permanent characteristics of the university. With the possible exception of location, all these characteristics are in the strength of institution to be applied and modified from time to time. However, they belong to a relatively stable short-term factor. For example, implementing a new program usually includes many faculty committees, institutional reviews, and frequently state agreement. Decreasing the fees usually depends on the search of income source or another fund-cutting program. The main point is that this institutional character tends to define the institution in a short-term. Moreover, during the implementation of change (e.g., adding a new program), it is possible to take a longer time for image and reputation to change the student candidate, parents, and guidance counselor's perspective. For that reason, this variable is included in the model as a relatively permanent characteristic.

\section{METHODS OF RESEARCH}

The research design was explanatory research. Explanatory research is conducted in order to identify the extent and nature of cause-and-effect relationships (Hermawan, 2009). explanatory research can be conducted in order to assess impacts of specific changes on existing norms, various processes etc. Causal studies focus on an analysis of a situation or a specific problem to explain the patterns of relationships between variables. Experiments are the most popular primary data collection methods in studies with causal research design. This research aimed at giving an empirical proof on the influence of promotion and service quality on student decision in selecting private university in Palembang city as well as the moderating variable of promotion influence on student decision in selecting the private university in Palembang city.

The data collection was conducted by distributing a survey to the research respondents who were active students at Universitas Muhammadiyah Palembang, Universitas Palembang, Universitas IBA, Universitas Tridinanti, Universitas Tamansiswa, Universitas Sjakhyakirti, Universitas PGRI Palembang, Universitas Kader Bangsa, Universitas Bina Darma, Universitas Indo Global Mandiri, Universitas Musi Charitas. The instrument used was a questionnaire. It was a cross-sectional period study, which only examined a particular time with many respondents.

The population in this research consisted of students from 11 private universities in Palembang city. Based on the data of Pangkalan Data Universitas (University Data Base) in February 2018, there were 45,134 active students. The number of samples as the respondents of this research were calculated using the following Slovin's formula:

$$
\begin{gathered}
\mathrm{n}=\frac{\mathrm{N}}{1+\mathrm{Ne}^{2}} \\
\mathrm{n}=\frac{45134}{1+45134 \times 0.05^{2}} \\
\mathrm{n}=399.99 \text { rounded up to } 400 \text { samples }
\end{gathered}
$$


The data analysis used in this quantitative research was Structural Equation Modelling (SEM) which was initially begun with the testing of the variables using confirmatory factor analysis. The SEM model was also analyzed to obtain and evaluate the matching of proposed. Furthermore, the sampling was conducted employing a stratified random sampling method with the distribution as the following.

Table 1 - Distribution of Research Respondents

\begin{tabular}{|l|l|l|}
\hline Universities & Number of Students & Fraction samples \\
\hline Universitas Muhammadiyah Palembang & 10829 & 96 \\
\hline Universita Palembang & 1011 & 8 \\
\hline Universitas IBA & 859 & 8 \\
\hline Universitas Tridinanti & 5737 & 52 \\
\hline Universitas Tamansiswa & 2076 & 20 \\
\hline Universitas Sjakhyakirti & 3602 & 32 \\
\hline Universitas PGRI Palembang & 7907 & 68 \\
\hline Universitas Kader Bangsa & 1713 & 16 \\
\hline Universitas Bina Darma & 7229 & 64 \\
\hline Universitas Indo Global Mandiri & 1871 & 16 \\
\hline Universitas Katolik Musi Charitas & 2300 & 20 \\
\hline Total & 45134 & 400 \\
\hline
\end{tabular}

\section{RESULTS AND DISCUSSION}

In this section, the hypothesis testing results were described including the influence of exogenous variable (promotion and Service Quality) on an endogenous variable (University Selection Decision) with Permanent university characteristic as moderating variable.

In the SEM analysis, an indicator is stated as having a good validity if it has a factor loading higher than 0.70 (Gunarto, 2018). The evaluation on the construct reliability value was measured by composite reliability. Each construct is stated as reliable if it has a higher composite reliability than 0.70 and higher AVE than 0.50 (Gunarto, 2018).

The final model formation of promotion variable is as presented in Figure 2.

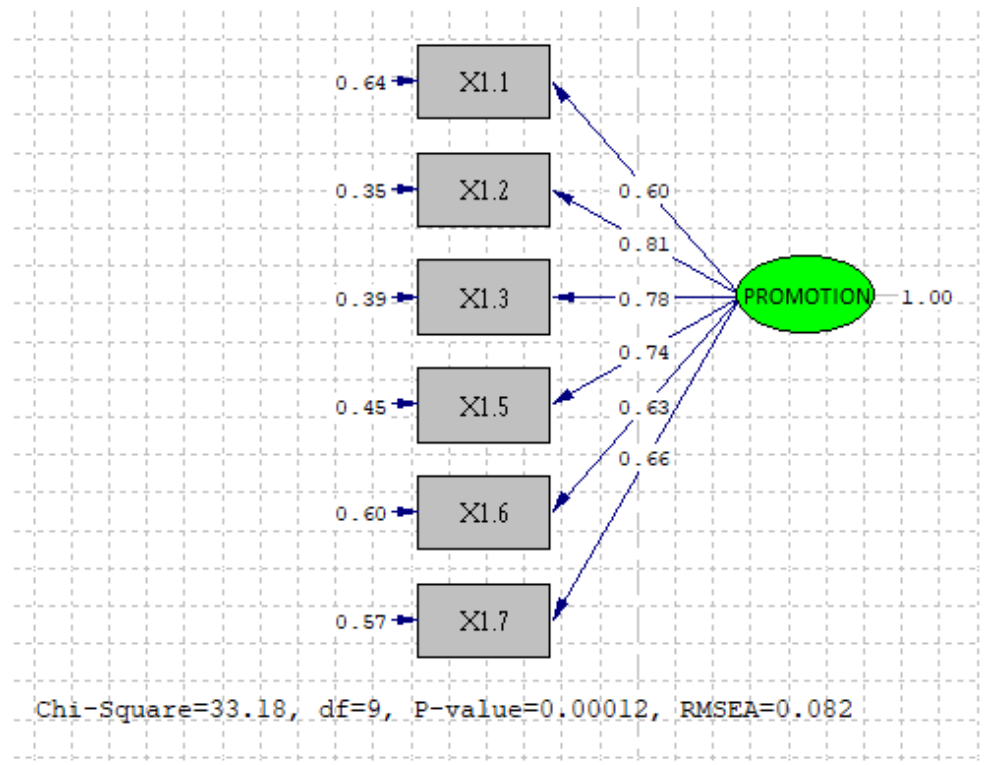

Figure 2 - The Estimation Results of Promotion CFA Final Model

From the results of promotion variable CFA final model formation, it generated factor loading value for all indicators was higher than 0.5 , and the reliability value of Promotion variable is as described in Table 2. 
Eurasia: Economics \& Business, 2(20), February 2019

DOI https://doi.org/10.18551/econeurasia.2019-02

Table 2 - Factor Loading and End of Promotion Model Reliability Scores

\begin{tabular}{|c|c|c|c|c|}
\hline Indicator & Factor loading $(\lambda)$ & Squared Factor loading $\left(\lambda^{2}\right)$ & $\begin{array}{l}\text { Error } \\
\text { (e) }\end{array}$ & Description \\
\hline $\mathrm{X} 1.1$ & 0.60 & 0.36 & 0.64 & Valid \\
\hline $\mathrm{X} 1.2$ & 0.81 & 0.66 & 0.34 & Valid \\
\hline $\mathrm{X} 1.3$ & 0.78 & 0.61 & 0.39 & Valid \\
\hline $\mathrm{X} 1.5$ & 0.74 & 0.55 & 0.45 & Valid \\
\hline $\mathrm{X} 1.6$ & 0.63 & 0.40 & 0.60 & Valid \\
\hline $\mathrm{X} 1.7$ & 0.66 & 0.44 & 0.56 & Valid \\
\hline Total & 4.22 & 3.00 & 3.00 & \\
\hline Construct Reliability $(C R)$ & \multicolumn{3}{|c|}{0.95} & \multirow{2}{*}{ Reliable } \\
\hline Average Variance Extract (AVE) & \multicolumn{3}{|c|}{0.65} & \\
\hline
\end{tabular}

Based on Table 2, Promotion final model with 11 indicators can be stated valid because all indicators have factor loading value $(\lambda)$ of more than 0.5 . The $C R$ value is higher than $0.7(\mathrm{CR}=0.95)$, and AVE value is more than $0.5(\mathrm{AVE}=0.65)$. This indicates that the indicators formulated in the Promotion variable final model are valid and reliable.

The matching test of Goodness of Fit in the Promotion variable final model generated results as presented in Table 3.

Table 3 - The Goodness of Fit (GOF) Results of Promotion Final Model

\begin{tabular}{llll}
\hline Criteria & Limit Value & Results & Conclusion \\
\hline$X^{2-}$ chi square, Significance probability & $p$-value $\geq 0.05$ & 0.00 & Unfit \\
GFI & $>0.90$ & 0.96 & Fit \\
AGFI & $>0.90$ & 0.92 & Fit \\
CFI & $>0.95$ & 0.99 & Fit \\
TLI or NFI & $>0.95$ & 0.99 & Fit \\
RMR & $\leq 0.10$ & 0.06 & Fit \\
RMSEA & $\leq 0.08$ & 0.08 & Fit \\
\hline
\end{tabular}

Source: SEM analysis.

In Table 3, there are several statistical criteria of goodness of fit (GOF) which do not fit such as Chi-Square. The small or non-significant chi-square value is difficult to be fulfilled particularly in a large sample. (Hair, Black, et al., 2014; Hoyle, 2012), however, it does not mean the model does not fit. Therefore, it is suggested to use other matching criteria (Hair et al., 2014). As aforementioned that significant $p$-value does not always mean that the model is not good, because $p$-value is influenced by the number of samples (Gunarto, 2018). Several statistical criteria of goodness of fit (GOF) such as GFI, AGFI, CFI, TLI, RMR, and RMSEA, so that the final measurement model of promotion variable has fulfilled fit measurement model criteria and can be a manifest for Promotion construct variable.

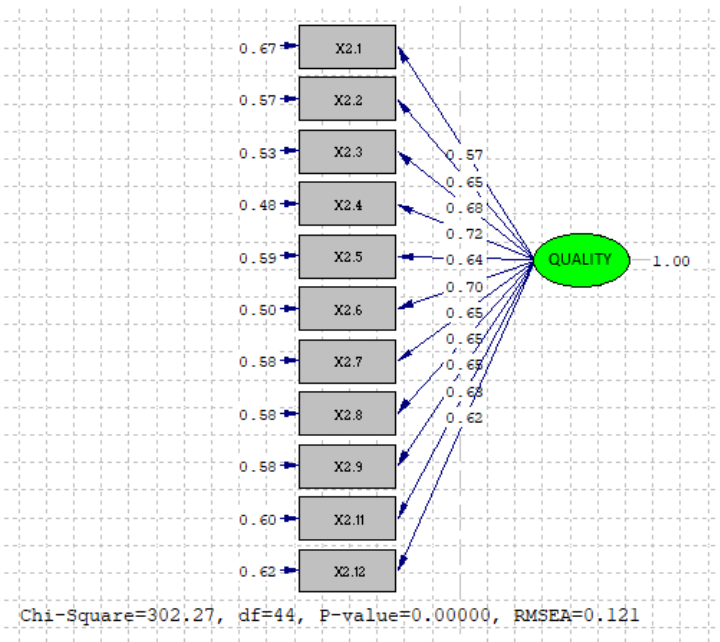

Figure 3 - The Estimation Results of Service Quality CFA Final Model 
The results of Service Quality variable CFA final model formation generated factor loading value for all indicator is higher than 0.5 , and the reliability value of Service Quality variable is described in Table 4.

Table 4 - Factor Loading and Reliability Scores of Service Quality Final Model

\begin{tabular}{|c|c|c|c|c|}
\hline Indicator & Factor loading $(\lambda)$ & $\begin{array}{c}\text { Squared } \\
\text { Factor loading }\left(\lambda^{2}\right)\end{array}$ & $\begin{array}{c}\text { Error } \\
(\mathrm{e})\end{array}$ & Desc. \\
\hline $\mathrm{X} 1.1$ & 0.81 & 0.66 & 0.34 & Valid \\
\hline $\mathrm{X} 1.2$ & 0.92 & 0.85 & 0.15 & Valid \\
\hline $\mathrm{X} 1.3$ & 0.74 & 0.55 & 0.45 & Valid \\
\hline $\mathrm{X} 1.4$ & 0.80 & 0.64 & 0.36 & Valid \\
\hline $\mathrm{X} 1.5$ & 0.75 & 0.56 & 0.44 & Valid \\
\hline $\mathrm{X} 1.6$ & 0.80 & 0.64 & 0.36 & Valid \\
\hline X1.7 & 0.88 & 0.77 & 0.23 & Valid \\
\hline X1.8 & 0.87 & 0.76 & 0.24 & Valid \\
\hline X1.9 & 0.70 & 0.49 & 0.51 & Valid \\
\hline X1.10 & 0.76 & 0.58 & 0.42 & Valid \\
\hline X1.11 & 0.70 & 0.49 & 0.51 & Valid \\
\hline Total & 0.78 & 0.61 & 0.39 & Valid \\
\hline Average Variance Extract (AVE) & 8.81 & 7.10 & 3.90 & Reliable \\
\hline
\end{tabular}

Based on Table 4, Service Quality final model with 11 indicators can be stated as valid because all indicators have factor loading value $(\lambda)$ of more than 0.5 . CR value is seen higher than $0.7(\mathrm{CR}=0.95)$, and $\mathrm{AVE}$ value is higher than 0.5 (AVE=0.65). This means that the indicators formulated in Service Quality variable final model are already valid and reliable.

The matching test results of Goodness of Fit in Service Quality final model generated results as presented in Table 5.

Table 5 - The Goodness of Fit (GOF) Results of Service Quality Final Model

\begin{tabular}{llll}
\hline Criteria & Limit Value & Results & Conclusion \\
\hline$X^{2-}$ chi square, Significance probability & $p$-value $\geq 0.05$ & 0.00 & Unfit \\
GFI & $>0.90$ & 0.96 & Fit \\
AGFI & $>0.90$ & 0.92 & Fit \\
CFI & $>0.95$ & 0.99 & Fit \\
TLI or NFI & $>0.95$ & 0.99 & Fit \\
RMR & $\leq 0.10$ & 0.06 & Fit \\
RMSEA & $\leq 0.08$ & 0.121 & Unfit \\
\hline
\end{tabular}

Source: SEM analysis.

In Table 5, there are several statistical criteria of goodness of fit (GOF) which are not fit such as Chi-Square and RMSEA. Several statistical criteria of statistical goodness of fit (GOF) such as GFI, AGFI, CFI, TLI, and RMR, so that the Service Quality measurement final model has fulfilled the criteria of fit measurement model and can be a manifest for Service Quality Construct variable.

The results of the Permanent university characteristic final model formation are displayed in Figure 4.

The CFA final model formation results of Permanent university characteristic variable generated factor loading value for all indicators is higher than 0.5 , and the reliability value of Permanent university characteristic variable is described in Table 6.

Based on Table 6 , the final model of Permanent university characteristic with 9 indicators has been stated as valid because all indicators have factor loading value $(\lambda)$ of more than 0.5. CR value has a higher value of more than $0.7(C R=0.95)$ and AVE value is more than $0.5(\mathrm{AVE}=0.65)$. This means that the indicators which have been formulated in the final model of Permanent University characteristic are valid and reliable.

The matching test results of Goodness of Fit in the final model of Permanent university characteristic in Table 7. 
Eurasia: Economics \& Business, 2(20), February 2019

DOI https://doi.org/10.18551/econeurasia.2019-02

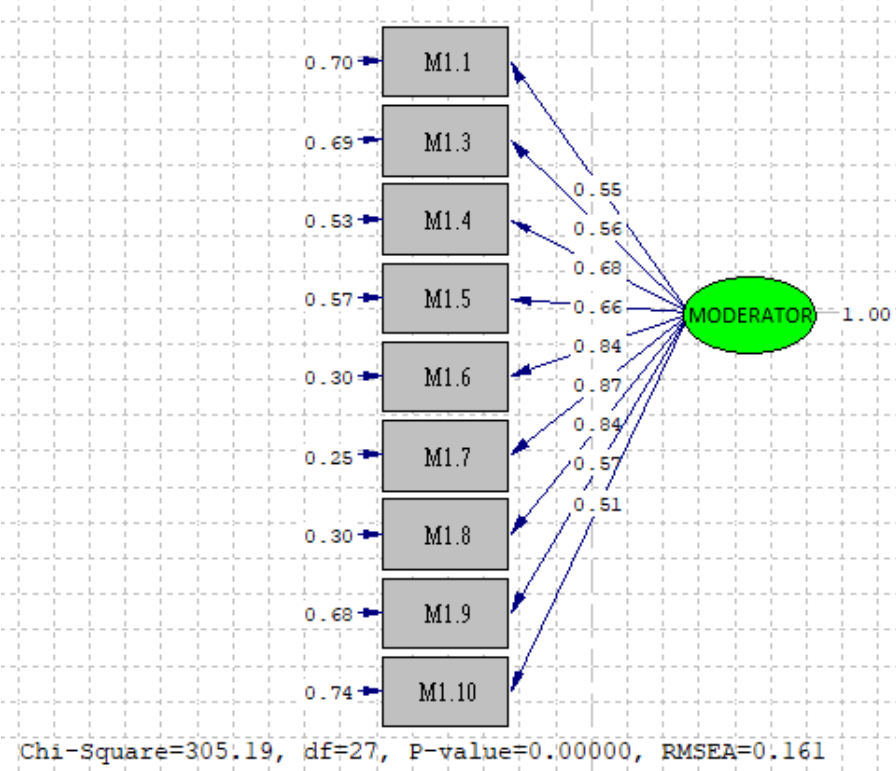

Figure 4 - The Estimation Results of Permanent university characteristic CFA Final Model

Table 6 - Factor Loading and Reliability Scores of Permanent university characteristic Final Model

\begin{tabular}{|c|c|c|c|c|}
\hline Indicator & $\begin{array}{c}\text { Factor loading } \\
(\lambda)\end{array}$ & $\begin{array}{c}\text { Squared } \\
\text { Factor loading }\left(\lambda^{2}\right)\end{array}$ & $\begin{array}{c}\text { Error } \\
(\mathrm{e})\end{array}$ & Description \\
\hline $\mathrm{X} 1.1$ & 0.81 & 0.66 & 0.34 & Valid \\
\hline $\mathrm{X} 1.2$ & 0.92 & 0.85 & 0.15 & Valid \\
\hline $\mathrm{X} 1.3$ & 0.74 & 0.55 & 0.45 & Valid \\
\hline $\mathrm{X} 1.4$ & 0.80 & 0.64 & 0.36 & Valid \\
\hline $\mathrm{X} 1.5$ & 0.75 & 0.56 & 0.44 & Valid \\
\hline $\mathrm{X} 1.6$ & 0.80 & 0.64 & 0.36 & Valid \\
\hline $\mathrm{X} 1.7$ & 0.88 & 0.77 & 0.23 & Valid \\
\hline $\mathrm{X} 1.8$ & 0.87 & 0.76 & 0.24 & Valid \\
\hline $\mathrm{X} 1.9$ & 0.70 & 0.49 & 0.51 & Valid \\
\hline $\mathrm{X} 1.10$ & 0.76 & 0.58 & 0.42 & Valid \\
\hline $\mathrm{X} 1.11$ & 0.70 & 0.49 & 0.51 & Valid \\
\hline $\mathrm{X} 1.12$ & 0.78 & 0.61 & 0.39 & Valid \\
\hline Total & 8.81 & 7.10 & 3.90 & \multirow{2}{*}{ Reliable } \\
\hline Construct Reliability (CR) & \multicolumn{3}{|l|}{0.95} \\
\hline Average Variance Extract (AVE) & \multicolumn{3}{|l}{0.65} \\
\hline
\end{tabular}

Table 7 - The Goodness of Fit (GOF) Results of Permanent university characteristic Final Model

\begin{tabular}{llll}
\hline Criteria & Limit Value & Results & Conclusion \\
\hline$X^{2}$ chi square, Significance probability & $p$-value $\geq 0.05$ & 0.00 & Unfit \\
GFI & $>0.90$ & 0.96 & Fit \\
AGFI & $>0.90$ & 0.92 & Fit \\
CFI & $>0.95$ & 0.99 & Fit \\
TLI or NFI & $>0.95$ & 0.99 & Fit \\
RMR & $\leq 0.10$ & 0.06 & Fit \\
RMSEA & $\leq 0.08$ & 0.16 & Unfit \\
\hline
\end{tabular}

Source: SEM analysis.

In Table 7, there are several statistical criteria of goodness of fit (GOF) which are not fit such as Chi-Square and RMSEA. Several statistical criteria of goodness of fit (GOF) such as GFI, AGFI, CFI, TLI, and RMR, so that the final measurement model of Permanent university characteristic has fulfilled fit measurement model criteria and can be a manifest for Permanent university characteristic Construct variable.

The results of the final model formation of University Selection Decision variable can be seen in Figure 5. 


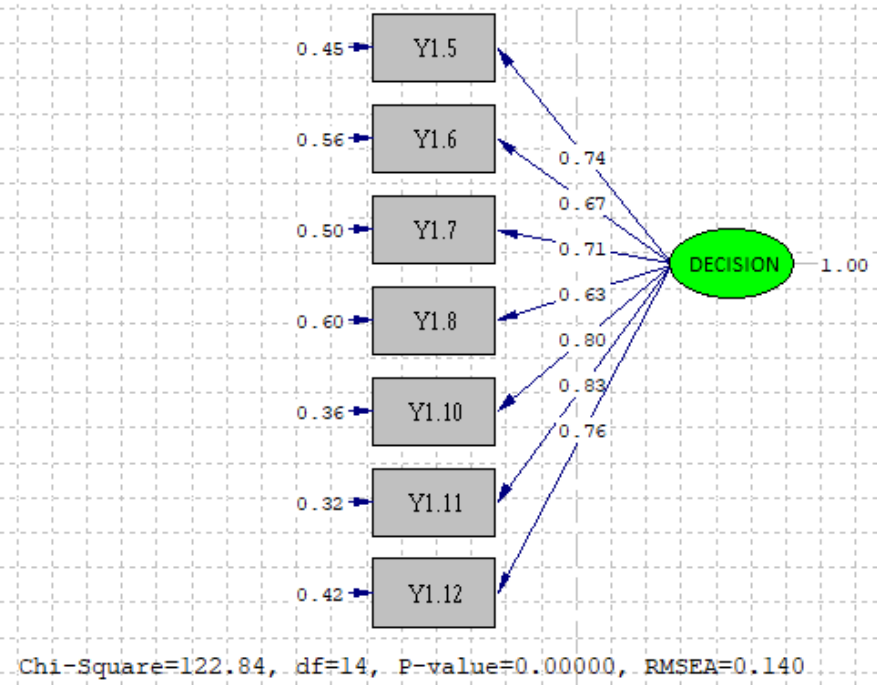

Figure 5 - The Estimation Results of University Decision CFA Final Model

The results of CFA final model formation of University Selection Decision variable generated factor loading value for all indicators higher than 0.5 , and the reliability value of the University Selection Decision variable is explained in Table 8.

Table 8 - Factor Loading and Reliability Scores of University Selection Decision Final Model

\begin{tabular}{|c|c|c|c|c|}
\hline Indicator & $\begin{array}{c}\text { Factor loading } \\
(\lambda)\end{array}$ & $\begin{array}{c}\text { Squared } \\
\text { Factor loading }\left(\lambda^{2}\right)\end{array}$ & $\begin{array}{c}\text { Error } \\
(\mathrm{e})\end{array}$ & Description \\
\hline $\mathrm{X} 1.1$ & 0.81 & 0.66 & 0.34 & Valid \\
\hline $\mathrm{X} 1.2$ & 0.92 & 0.85 & 0.15 & Valid \\
\hline $\mathrm{X} 1.3$ & 0.74 & 0.55 & 0.45 & Valid \\
\hline $\mathrm{X} 1.4$ & 0.80 & 0.64 & 0.36 & Valid \\
\hline $\mathrm{X} 1.5$ & 0.75 & 0.56 & 0.44 & Valid \\
\hline $\mathrm{X} 1.7$ & 0.80 & 0.64 & 0.36 & Valid \\
\hline $\mathrm{X} 1.8$ & 0.88 & 0.77 & 0.23 & Valid \\
\hline $\mathrm{X} 1.9$ & 0.87 & 0.76 & 0.24 & Valid \\
\hline $\mathrm{X} 1.10$ & 0.70 & 0.49 & 0.51 & Valid \\
\hline X1.11 & 0.76 & 0.58 & 0.42 & Valid \\
\hline X1.12 & 0.70 & 0.49 & 0.51 & Valid \\
\hline Total & 0.78 & 0.61 & 0.39 & Valid \\
\hline Construct Reliability (CR) & 8.81 & 7.10 & 3.90 & Reliable \\
\hline
\end{tabular}

Based on Table 8, the final model of University Selection Decision with 7 indicators can be stated as valid because all indicators have factor loading value $(\lambda)$ of more than 0.5 . The $\mathrm{CR}$ value is higher than 0.7 ( $\mathrm{CR}=0.95)$, and AVE value is more than 0.5 (AVE=0.65). This signifies that the indicators which have been formulated in the final model of University are already valid and reliable. The matching trust results of Goodness of Fit in the final model of University Selection Decision generated results as presented in Table 9.

Table 9 - The GOF Results of University Selection Decision Final Model

\begin{tabular}{llll}
\hline Criteria & Limit Value & Results & Conclusion \\
\hline$X^{2-}$ chi square, Significance probability & $p$-value $\geq 0.05$ & 0.00 & Unfit \\
GFI & $>0.90$ & 0.96 & Fit \\
AGFI & $>0.90$ & 0.92 & Fit \\
CFI & $>0.95$ & 0.99 & Fit \\
TLI or NFI & $>0.95$ & 0.99 & Fit \\
RMR & $\leq 0.10$ & 0.06 & Fit \\
RMSEA & $\leq 0.08$ & 0.14 & Unfit \\
\hline
\end{tabular}

Source: SEM analysis. 
Eurasia: Economics \& Business, 2(20), February 2019

DOI https://doi.org/10.18551/econeurasia.2019-02

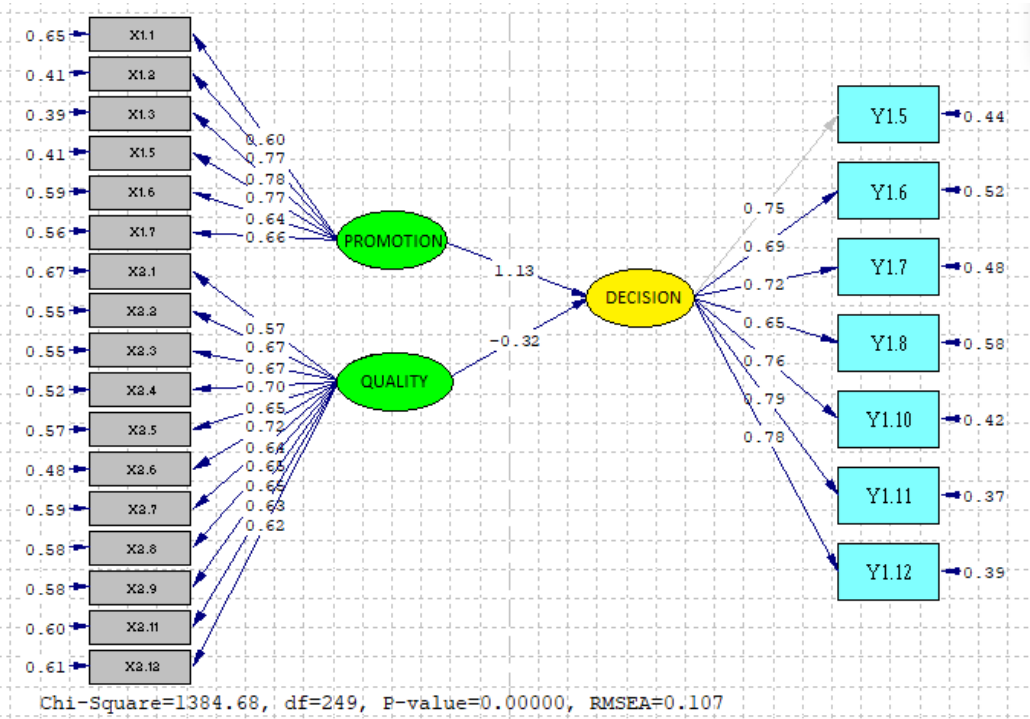

Figure 6 - Full Model Estimation Results

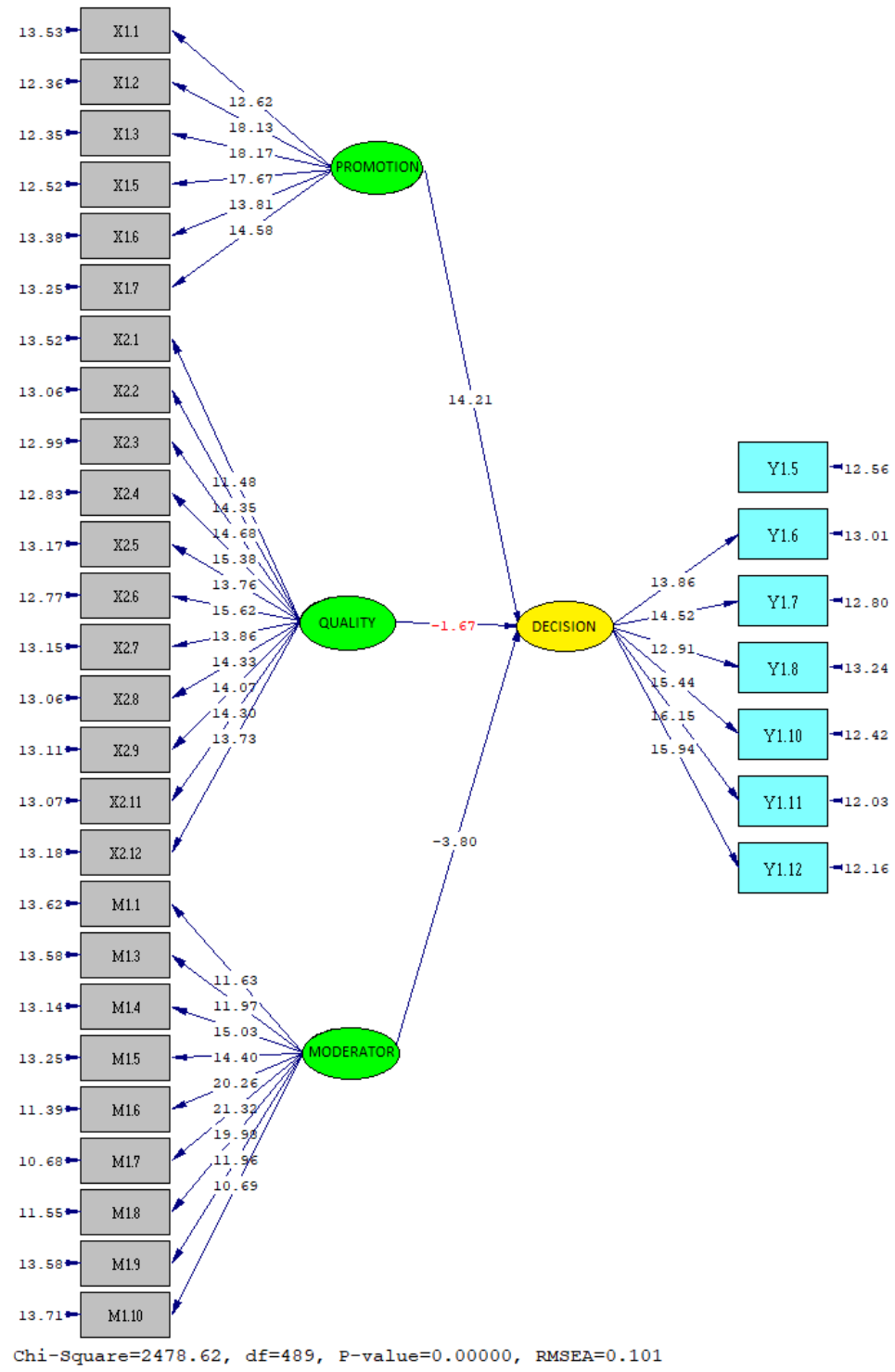

Figure 7 - Full Model Test Results with Moderator 
In Table 9, there are several statistical criteria of goodness of fit (GOF) which do not yet fit such as Chi-Square and RMSEA. Several statistical criteria of goodness of fit (GOF) such as GFI, AGFI, CFI, TLI, and RMR, so that the final measurement model of University Selection Decision has fulfilled the fit measurement model criteria and can be a manifest for construct variable of University Selection Decision.

The estimation results for the initial structural model analysis is presented in Figure 6.

Figure 6 shows the values of parameter estimates in the correlation between existing latent variables and the values of loading factor estimates of each indicator forming latent variables. As seen in the existing parameter values, there are negative and positive correlations between exogenous and endogenous variables. In which with the entry of the moderating variable, it can increase the correlation between university promotion and university selection decision and decrease the correlation between service quality and university selection decision.

Figure 7 shows that testing results are for measurement model and structural model with moderating variable (University Permanent Characteristic). All parameters were tested with t-test statistics where the significance testing is performed if the obtained t-value is more than 1.96, and on the other hand, if the obtained t-count is smaller than 1.96, then the parameters are not statistically significant. Figure 4.24 shows that almost all indicators forming latent variable and structural model are substantial because the t-value obtained is higher than 1.96, except for the correlation between quality and university selection decision which is statistically not significant. This occurs because there is a moderating variable (University Permanent Characteristic) which causes the weakening correlation between service quality and university selection decision.

Table 10 - Test Results of Correlations between Latent Variables

\begin{tabular}{llllllll}
\hline Endogenous Variable & & Exogenous Variable & Estimate & S.E. & t- Value & Desc. & $R^{2}$ \\
\hline DECISION & $<---$ & PROMOTION & 1.15 & 0.08 & 14.21 & Non-significant & \\
DECISION & $<---$ & QUALITY & -0.13 & 0.08 & -1.67 & Non-significant & 0.91 \\
DECISION & $<---$ & MODERATOR & -0.25 & 0.07 & -3.80 & Significant & \\
\hline
\end{tabular}

Based on Table 10, from 3 (three) proposed hypotheses, there is an accepted hypothesis (significant), and there are rejected hypotheses (not significant). The followings are the explanations of each hypothesis:

There is a positive correlation between promotion and University Selection Decision as much as 1.15 with a t-value of 14.21 . Statistically, it can be stated that the correlation is significant because the t-value is higher than t-table (1.96). This means that the better the promotion performed, the higher the students' University Selection Decision. The correlation between variables is stronger than the initial model before the existence of the moderating variable. This indicates that the Permanent university characteristic variable acts as a strengthening moderating variable. The result of this study are in line with Zainal, Tahir dan Ibrahim (2013), Aydin (2015) and Kusumawati (2013) with the result of the study finding that promotion has a significant effect on university selection decisions.

There is a negative correlation between Service Quality and University Selection Decision as much as 0.13 with a t-value of -1.67 . Statistically, it can be stated that there is no significant correlation because $\mathrm{t}$-value is smaller than $\mathrm{t}$-table (1.96)). This signifies that the Permanent university characteristic variable weakens the correlation between service quality and University Selection Decision. The result of this study are in line with Weisstein et. al. (2017), the finding that service quality has a negative effect on university selection decisions.

There is a negative correlation between Permanent university characteristic and University Selection Decision as much as 0.25 with a t-value of -3.80 . Statistically, it can be stated that there is a significant correlation because t-value is smaller than t-table (1.96). This means that the Permanent university characteristic variable has a significant negative correlation with the University Selection Decision. In order to see whether this moderating variable's role is significant or not, the interaction between the independent variables needs 
to be observed. The research that supports these results is Gaultier-Gaillard \& Louisot (2006), Wedlin (2006), Ressler \& Abratt (2009).

Moderating effects can be tested including by constructing an interaction model between the independent variable and the moderating variable. Furthermore, by using a multiple-regression analysis, it can be seen how the moderating variable's role whether it can weaken or strengthen the correlation between variables.

Table 11 - Multiple Regressions

\begin{tabular}{|c|c|c|c|c|c|}
\hline \multirow[b]{2}{*}{ Model } & \multicolumn{2}{|c|}{ Unstandardized Coefficients } & Standardized Coefficients & \multirow[b]{2}{*}{$\mathrm{T}$} & \multirow[b]{2}{*}{ Sig. } \\
\hline & $B$ & Std. Error & Beta & & \\
\hline 1 (Constant) & 13.180 & 1.950 & & 6.758 & .000 \\
\hline PROMOTION (X1) & -1.162 & .229 & -1.366 & -5.069 & .000 \\
\hline$\overline{\text { SERVICE (X2) }}$ & .516 & 229 & .463 & 2.253 & .025 \\
\hline MODERATOR (M) & -1.497 & 252 & -2.188 & -5.928 & .000 \\
\hline X1_M & 231 & .032 & 3.940 & 7.298 & .000 \\
\hline $\mathrm{X} 2 \mathrm{M}$ & .042 & .033 & -.676 & -1.278 & 202 \\
\hline
\end{tabular}

Based Table 11 above, moderating variable has a role in increasing the correlation between promotion and university selection decision. However, it does not significantly influence the correlation between quality and university selection decision due to its nonsignificant interaction value.

\section{CONCLUSION}

University Selection Decision has been proven to be significantly influenced by promotion and service quality.

The research results showed that the Permanent university characteristic variable becomes the moderating variable which can increase the influence of promotion on University Selection Decision.

Promotion Variable significantly contributes to the University Selection Decision, while Service Quality does not significantly influence University Selection Decision.

\section{REFERENCES}

1. Ancheh, K. S. B., Krishnan, A. \& Nurtjahja, O. (2007). Evaluative Criteria for Selection of Private Universities and Colleges in Malaysia. Journal of International Management Studies, 2(1), 1-11.

2. Aydin, S. (2015). The Analysis Of Antecedents Of Customer Loyalty In The Turkish Mobile Telecommunication Market. European Journal of Marketing, 39(7/8), 910-925.

3. Blackwell, R. D., Miniard, P. W., \& Engel, J. F. (2001). Consumer Behavior. MO: Harcourt College Publishers.

4. Bowen., \& Booms, B. H. (1983). The marketing aspects of service quality in Berry, L., Shostack, G., \& Upah, G. (eds.). Emerging perspectives on services marketing: American Marketing Association Chicago.

5. Briggs, S. (2007). An Exploratory Study of The Factors Influencing Undergraduate Student Choice: The Case of Higher Education In Scotland. Journal Studies in Higher Education, 21(6), , 705-722.

6. Burnett, J. J. (2000). Promotion Management. Boston: Houghton Mifflin.

7. Cabrera, A. F., \& La Nasa, S. M. (2000). Understanding the College-Choice Process. New Directions for Institutional Research, 107, 5-22.

8. Ceja, M. (2006). Understanding the Role of Parents and Siblings as Information Sources in the College Choice Process of Chicana Students. Journal of College Student Development, 47(1), 87-104.

9. Chapman, D. W. (1981). A Model of Student College Choice. Journal of Higher Education. 52(5), 490-505. 
10. Garvin, D. A. (1987). Quality on the Line. Harvard Business Review, 61(8-9), 65-73.

11. Gaultier-Gaillard, S., \& Louisot, J.-P. (2006). Risk to Reputation : A Global Approach. The Geneva Papers on Risk and Insurance. Issues and Practice, 31(3), 425-445.

12. Gitosudarmo, I. (2010). Manajemen Pemasaran. Yogyakarta: BPFE.

13. Gray, B. J., Fam, K. S., \& Llanes, V. A. (2003). Branding universities in Asian markets. Journal of Product and Brand Management, 12(2), 108-120.

14. Gunarto, M. (2018). Analisis Statistik dengan Model Persamaan Struktural (SEM): Teoritis dan Praktis. Bandung: Alfabeta.

15. Hair, J. E., Jr et al. (2014). A Primer on Partial Least Squares Structural Equation Modelling (PLS-SEM). USA: SAGE Publications, Inc.

16. Hermawan, A. (2009). Penelitian Bisnis. Jakarta: PT. Grasindo.

17. Johnston, M. W. (2010). Essentials of Marketing Management. New York: Mc. Graw Hill International Edition.

18. Joseph, M., \& Joseph, B. (1998). Identifying needs of potential students in tertiary education for strategy development. Quality Assurance in Education, 6(2), 90-96.

19. Joseph, M., \& Joseph, B. (2000). Indonesian student's perceptions of choice criteria in the selection of a tertiary institution: strategic implications. The International Journal of Educational management, 14(1), 40-44.

20. Karp, F. M. (2012). Test of a Model of Domain Satisfactions and Well-Being: Equity Considerations. Research on Aging, 4, 503-522.

21. Kartajaya, H. (2007). Boosting Loyalty Marketing Performance: Menggunakan Teknik Penjualan, Customer Relationship Management, dan Servis untuk Mendongkrak Laba. Bandung: Mizan Pustaka.

22. Kotler, P., \& Armstrong, G. (2008). Prinsip-Prinsip Pemasaran (12 ${ }^{\text {th }}$ Ed). Jakarta: Erlangga.

23. Kotler, P., \& Armstrong, G. (2012). Prinsip-Prinsip Pemasaran (13th Ed). Jakarta: Erlangga.

24. Kotler, P., \& Fox, K. (1995). Strategic Marketing for Educational Institutions (2 ${ }^{\text {nd }}$ Ed). New Jersey: Prentice Hall, Inc.

25. Kotler, P. (1997). Manajemen Pemasaran Analisis Perencanaa, Impelementasi, dan Pengendalian (Terjemahan Jaka Wasana). Jakarta: Salemba Empat.

26. Kusumawati, A. (2013). A Qualitative Study Of The Factors Influencing Student Choice : The Case Of Public University In Indonesia. Journal of Basic and Applied Scientific Research, 3(1), 314-327.

27. Lewis, R. C., \& Booms, B. H. (1983). The marketing aspects of service quality in Berry, L., Shostack, G. and Upah, G. (eds.). Emerging perspectives on services marketing: American Marketing Association Chicago.

28. Lin, L. (1997). What are student education and educational related needs? Marketing and Research Today, 25(3), 199-212.

29. Oliver, S. (2007). Strategi Public Relations. Jakarta: Esensi.

30. Parasuraman, A. A., Zeithaml, V., \& Berry, L. (2004). A Conceptual Model of Service Quality and Its Implication for Future Research. Journal of Marketing, 49(3), 123-131.

31. Payne, A. (2000). The Essence of Services Marketing. Translated by Fandy Tjiptono. Yogyakarta: Andi.

32. Ressler, J., \& Abratt, R. (2009). Assessing the impact of university reputation on stakeholder intentions. Journal of General Management, 35(1), 35-45.

33. Rudhumbu, N. (2014). Motivational Strategies in the Teaching of Primary School Mathematics in Zimbabwe. International Journal of Education Learning and Development, 2(2), 76-103.

34. Schiffman., \& Kanuk. (2007). Perilaku Konsumen. Jakarta: PT. Indeks.

35. Sidin, M. S., Hussin, S. R., \& Tan, S. H. (2003). An exploratory study of factors influencing the college choice decision of undergraduate students in Malaysia. Asia Pacific Management Review, 8(3), 259-280.

36. Tjiptono, F. (2010). Strategi Pemasaran. Yogyakarta: Andi Offset. 
37. Wedlin, L. (2006). Ranking Business Schools Forming Fields, Identities and Boundaries in International Management Education. USA: Edward Elgar Publishing Limited.

38. Weisstein, F. L., Lei Song., Peter, A., \& Ying Zhu. (2017). Examining Impacts of Negative Reviews and Purchase Goals on Consumer Purchase Decisions. Journal of Reatiling and Consumer Service, 39 (2017), 201-207.

39. Yavas, U., Benkenstein, M., \& Stuhldreier,U. (2004). Relationships between service quality and behavioral outcomes: A study of private bank customers in Germany. International Journal of Bank Marketing, 22(2), 144-157.

40. Zainal, O. M., Muhammad, T. J., \& Andy, B, I. (2013). Factors Influencing Students' Decisions In Choosing Private Institutions Of Higher Education In Malaysia : A Structural Equation Modelling Approach. Asian Academy of Management Journal, 18(1), 75-90.

41. Zinkhan, G. M. (1992). Green Advertising And The Reluctant Consumer. Journal of Advertising, 24(2), 1-5. 